\title{
Travel motives of German tourists in the Scandinavian mountains: the case of Fulufjället National Park
}

\section{Mareike Garms, Peter Fredman \& Ingo Mose}

To cite this article: Mareike Garms, Peter Fredman \& Ingo Mose (2017) Travel motives of German tourists in the Scandinavian mountains: the case of Fulufjället National Park, Scandinavian Journal of Hospitality and Tourism, 17:3, 239-258, DOI: 10.1080/15022250.2016.1176598

To link to this article: https://doi.org/10.1080/15022250.2016.1176598

\section{Published online: 30 Apr 2016.}

Submit your article to this journal ¿

Џll Article views: 460

Q View related articles $\sqsubset$

View Crossmark data $\longleftarrow$

Citing articles: 11 View citing articles $[7$ 


\title{
Travel motives of German tourists in the Scandinavian mountains: the case of Fulufjället National Park
}

\author{
Mareike Garms ${ }^{\mathrm{a}}$, Peter Fredman ${ }^{\mathrm{b}}$ and Ingo Mose ${ }^{\mathrm{a}}$ \\ ${ }^{a}$ Carl von Ossietzky University of Oldenburg, Applied Geography and Environmental Planning Research \\ Group, Oldenburg, Germany; ${ }^{b}$ Norwegian University of Life Sciences, Ås, Norway
}

\begin{abstract}
This paper investigates the travel motives of German visitors to Fulufjället National Park (FNP). The park attracts more than onethird international visitors, which is a high proportion compared to other regions in the Scandinavian mountains. Data for this study were derived from a mixed-method approach including a visitor survey and on-site interviews conducted in summer 2014. Factor and reliability analysis revealed, along with the usage of recreational experience preference scales, five motivational factors with an appropriate internal consistency including focus on self, nature, freedom, others, and experiences. As a result, the selfrelated and socialness factors play a subordinate role within the travel decision of German visitors. Instead, it is the outstanding scenery of FNP that provides German visitors with rewarding experiences in the Scandinavian "wilderness". Results from the study are discussed with respect to national park management and business development.
\end{abstract}

\section{ARTICLE HISTORY}

Received 30 October 2015

Accepted 5 April 2016

\section{KEYWORDS}

Travel motive; REP scales; national park; wilderness experience

\section{Introduction}

It has long been acknowledged that tourism can be a beneficial and effective instrument for the management and protection of national parks (Eagles, McCool, \& Haynes, 2002). The expected growth in international travel and demand for nature experiences suggest that the importance of tourism as a conservation tool will further increase in the future (Bushell \& Eagles, 2007). A recent study of protected area visitation globally shows that eight billion visits per year generate approximately US $\$ 600$ billion per year in direct expenditure and US $\$ 250$ billion in consumer surplus (Balmford et al., 2015). In order to ensure the long-term sustainability of tourism operations, protected area managers have to pay increasing attention to the type and quality of visitor experiences (Eagles, 2014; Manning, 2012). Thus, the investigation of motivations builds the foundation for further behavioural examinations because of an inseparable connection with the travel decision process, including on-site perceptions, experiences, and the satisfaction level (Mansfeld, 1992). The development of effective and comprehensive management strategies based on customized knowledge contributes to maximize visitor's nature 
experience, and ensure the enjoyment of recreational opportunities, and the sustainment of the tourism resource itself - the valued status of the natural setting.

Fulufjället National Park (FNP) is located in the southern mountain region of Sweden and Norway. Recent studies found that Germans are the largest foreign visitor group in this park (Fredman \& Wikström, 2015). This is not surprising because $9 \%$ of about 1.5 million German tourists to Sweden visited the region "North Middle Sweden" where FNP is located in 2013 (IBIS, 2013). Previous visitor studies in the area showed that Germans experienced FNP as being "very magnificent" and had strong experiences of tranquil, pure, and unspoiled nature (Fredman, Hörnsten Friberg, \& Emmelin, 2005). These data also indicate that German visitors are more likely to visit Fulufjället because of the national park status than Swedish visitors (Wall-Reinius \& Fredman, 2007).

While some hints regarding the appreciation of FNP are given via previous quantitative surveys, there is still limited knowledge about the specific motives of this important international visitor category. Thus, it is the aim of this paper to find relevant motive segments for German FNP visitors with the help of recreational experience preference (REP) scales, and giving quantitative survey categories more significance through contextualized indepth interviews. Thus, a mixed-method approach was applied where the phases of field research were simultaneous. A subsequent importance rating of motivational factors is crucial for business as well as management interests, and an exploratory research design appeared to be the ideal way to provide such insights. The study was conducted by the European Tourism Research Institute (Etour) of Mid-Sweden University in cooperation with the Carl von Ossietzky University of Oldenburg in Germany.

The paper is divided into five sections. First, a theoretical framework explains tourist motivation models and motivational research in outdoor recreation, and sheds light on the image of Scandinavia. Then the case of FNP is reviewed in detail. After clarification of the research procedures, an analysis of the requested motivational items follows. Subsequently, the qualitative interviews supplement the motivational interpretation and generate additional facts. The paper closes with final remarks, possible future research topics, followed by implications for tourism and national park management.

\section{Theoretical background}

\section{REP scales}

Early motivational studies generally employed open-ended questions to explore potential motivations. The responses were instrumental in the formulation of motivational constructs (Manning, 1999). Over the years, motives have been studied more systematically. The major part of motivational research builds on conceptual and empirical work dealing with REP scales inspired by the expectancy valence model (see Borrie \& Birzell, 2001). This managerial tool is based on the concept that recreation is more than participation in an activity (Driver \& Brown, 1975). These scales have been used to measure visitor preferences in a number of wilderness and non-wilderness areas (Borrie \& Birzell, 2001). The original REP scales of Driver (1983) were grouped into 19 domains and had a pool of 328 items. Typically, a subset of these items is used, depending on domains hypothesized to be important for the particular activity or setting (Manfredo \& Driver, 1996). Studies by Roggenbuck and Driver (2000) suggest that there are common 
motives for visiting wilderness, such as solitude and experiencing nature. But not all motives are shared by all visitors. Other studies have, for example, shown that motivation dimensions differ with respect to activity participation (Graefe, Thapa, Confer, \& Absher, 2000). Nature perceptions are determined by social and cultural conditions as much as by individual preferences and experiences.

\section{Travel motivation models}

Motivation theories applied to tourism typically try to find answers why people travel and they often come to the conclusion that people want to fulfil their needs and wants (Cooper, Fletcher, Gilbert, \& Wanhill, 2008). Pearce, Morrison, and Rutledge (1998) define tourist motivation more specifically, " (... ) as the global integrating network of biological and cultural forces which gives value and direction to travel choices, behavior and experience". But while it is often self-explanatory to describe the purpose of travelling (business and pleasure), it is more challenging to find the underlying and often hidden reasons (Pearce, 2005). Motivation also depends on numerous factors, for example demographic characteristics, the personality of the traveller, and past experiences (Swarbrooke \& Horner, 2007).

Crompton (1979), who developed the model of "push" and "pull" factors of destination choice, argued that travel motivation is a critical factor and a driving force behind tourist behaviour. The first factor describes an intrinsic force which "pushes" the tourist away from home. An unsatisfying condition at home generates the need for temporal isolation (Dann, 1981). In this context, Iso-Ahola (1982) constructed the escape-seeking dichotomy claiming that a free-time activity may produce satisfaction on two levels: it provides an intrinsic reward, and it helps to leave the common environment behind. The second factor assumes that the individual is attracted (in other words "pulled") by promising attributes of the destination. Marketing stimuli are able to shape these imaginations and have a growing effect on the society (Goossens, 2000). It is debatable which factor overbalances the travel decision and if a clear delimitation and definition of the two factors are possible (Mundt, 2013). Thus, it is helpful to see the model rather as a synergy of two interacting forces which lead to the visit of the holiday destination in the end.

There have also been attempts to categorize travel motivation of nature-based tourists in Scandinavia. Mehmetoglu (2007) identified six central travel motivations including nature, physical activities, novelty/learning, mundane everyday life, and ego/status in a study of nature-based tourists in Norway. Another Norwegian study of German, Dutch, and Danish motor tourists (Haukeland, Grue, \& Veisten, 2010) examined four factors of nature orientation including inspiration, recreation, challenge, and sightseeing. Earlier research in FNP found four domains (self-discovery, experience of places, seeking solitude, and challenging self) based on REP scales developed from wilderness use in the US (Raadik, Cottrell, Fredman, Ritter, \& Newman, 2010). This study applied 35 motivational items adapted from Newman and Dawson (1998) who conducted a study of High Peak Wilderness Areas in Adirondack State Park, New York, using the original scale developed by Driver (1983).

\section{Image of scandinavia}

Scandinavia is largely understood as a region with vast natural resources and unspoiled nature. Even more, much of Scandinavia is perceived as one of Europe's last 
"wildernesses", hardly found on the continent, and rather contrary to the majority of the cultural landscapes elsewhere. Large protected areas, especially national parks, build a major part of this image (Mose, 2007). Thus, experiencing unspoiled nature is considered a primary travel motive among foreign visitors of the Nordic countries (Gössling \& Hultman, 2006). The interest for Scandinavia as a travel destination among Germans also grows steadily, especially among people with a strong commitment to "ecological holidays" (F.U.R., 2014). Sweden in particular enjoys an exceptional role among the Scandinavian destinations. During 2013, Sweden recorded a total number of 18.8 million foreign visits and the largest market outside the Nordic countries was Germany with $8 \%$ of all visits (IBIS, 2013). A qualitative ranking shows that many Germans share a very distinctive perception of Sweden, "Sweden has the most beautiful landscapes of Scandinavia", and "Who is seeking silence will definitely be satisfied in Scandinavia" (B.A.T., 2006). Sweden is also known as the friendly country with "blue lakes, green forests and red huts", and Knoller (2014) pointed out that "every German somehow likes Sweden". The word "Bullerbysyndromet", invented by Berthold Franke of the Goethe Institute, describes the idyllic and idealized image of Sweden (Arthur, 2008). However, located in the mountains (the so-called fjell), FNP only partly embodies the typical image of Sweden's cultural heritage - it rather holds the image of "wilderness".

The Swedish mountains along the Norwegian boarder represent about one-third of Sweden's entire surface, but contain only $2 \%$ of the total population (Fredman \& Heberlein, 2005), and about $90 \%$ of Sweden's national parks' surface area are in the mountains. The mountain regions are among the more unspoiled parts of Sweden's countryside, which may also explain why many people perceive them as synonyms with recreation and relaxation (SEPA, 2009).

\section{Study setting - FNP}

\section{Area description}

FNP was established in 2002 and then became Sweden's 28th national park. It is located in the Municipality of Älvdalen in northwest Dalarna County (Figure 1). There is also a smaller Norwegian part of the massive which is protected as a national park since 2012. The Swedish part of the park covers 385 square kilometres with about $65 \%$ bare mountain and alpine heath (SEPA, 2002). The park exhibits extensive outdoor recreation facilities, with 140 kilometres of marked trails, and several cabins for brief rests or overnight stay. Njupeskär is Sweden's highest waterfall and, therefore, the park's most popular attraction. The establishment of the park involved an "inside-out" process where local interests were given high priority within a spatial planning framework (Wallsten, 2003). Following the national park designation in Fulufjället the area received a 40\% increase in visitation, from 38,000 visits in 2001 to 53,000 visits in 2003 (Fredman, Hörnsten Friberg, \& Emmelin, 2007). However, data from a more recent visitor survey at FNP showed that visitation has dropped since 2003 (the year after National Park inauguration) to levels only slightly higher than that of the year before the park was established (Fredman \& Wikström, 2015). This change is confirmed by the visitor counter at the entrance of the visitor centre. 


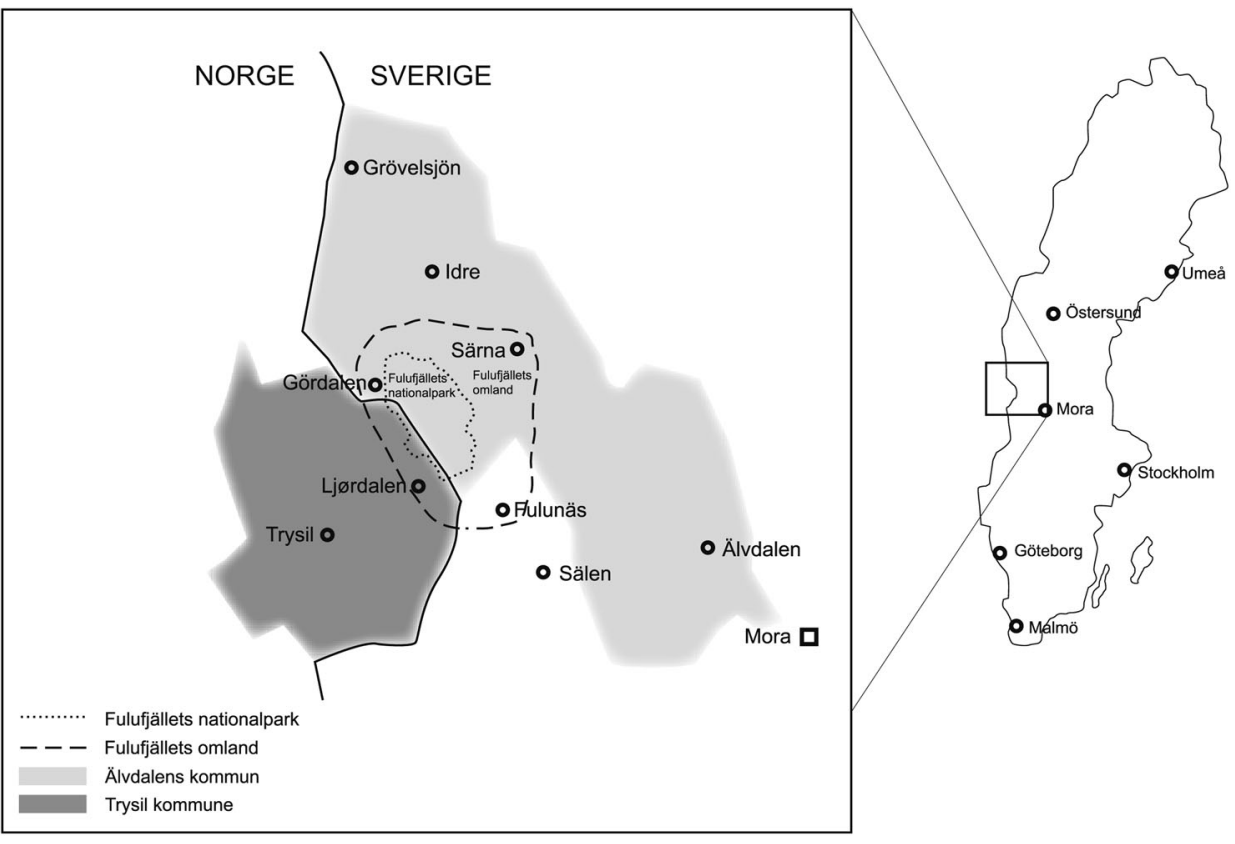

Figure 1. Map and location of Fulufjället National Park.

\section{Management of FNP}

Various visitor groups, from local to international, appreciate excellent opportunities to experience quietness, solitude, and wilderness in FNP. In order to guarantee the demanded conditions, the management plan and regulations are based on a division of the park into four zones based on the ROS (recreational opportunity spectrum) planning framework (Driver, Brown, Gregoire, \& Stankey, 1987) where directions and measures for use and protection vary between the zones. Most of the mountains above treeline are within the unspoiled so-called wilderness zone, comprising $60 \%$ of the park's total area. The wilderness area is kept free from roads, snowmobiles, hunting, and fishing. In this zone, activities that may disturb the natural environment or visitors' enjoyment of nature are highly restricted. The other three zones can be used more intensively for different purposes like fishing or snowmobiling (Fredman et al., 2005).

\section{Material and methods}

To meet the targets of the exploratory study, data were collected with a mixed-method research design where a quantitative (on-site contact cards with a follow-up online visitor survey) and a qualitative (semi-structured interviews) approach were combined. The more efficient instrument of quantitative research joined with contextualized indepth interviews built a base for a more comprehensive interpretation of data (Puhakka, Cottrell, \& Siikamäki, 2013). The mixed-method design thereby has a complementarity purpose in the sense of triangulation (see Molina-Azorín \& Font, 2015; Scholz \& Tietjen, 2002), which refers to the illustration and clarification of the quantitative 
survey results with findings from the interviews. Hence, the quantitative results provided the identification of five motivational factors and gave information about the level of importance, while the qualitative data provided a better understanding of these survey results. The two approaches were conducted simultaneously during the high-use summer season from early June to late September in 2014.

\section{Quantitative visitor survey}

Visitor data were gathered with the help of self-registration boxes at eight different locations in FNP. In total 3419 registration cards were collected during the summer season. A link to an electronic questionnaire in three possible languages (Swedish, English, and German) was sent by e-mail to 2711 visitors. Up to two reminders were sent out to those who had not answered. In sum, 475 persons received a German questionnaire version, 255 responded, and 184 approved that the place of residence is Germany. Thus, responses from 184 participants were used for further analysis.

The questionnaire included, besides for example social background characteristics, information about the visit and a reworked REP scale of 40 items within 10 domains (see Table 1). Motive statements were ranked on a 5-point Likert-type scale with the categories "not at all important" (1) to "extremely important" (5). Most of the items (33 items from Raadik et al., 2010) were previously found to be valid, reliable, and applicable to the Scandinavian context. Nevertheless, redundant items were excluded and scales were verified, adapted, and expanded through further literature review (Borrie \& Roggenbuck, 2001; Driver, 1983; Haukeland et al., 2010; Manfredo \& Driver, 1996).

\section{Qualitative in-depth interviews}

Complementary data were generated through semi-structured in-depth interviews with 30 German FNP visitors (14-77 years old). Study participants were a sample of the national park centre visitors during the high-use months of July and August. Within any sampled group, the research technician conveniently selected an individual or couple at the main entrance to report about specific travel motives and experiences. The semi-structured interview format allowed informants to elaborate their thoughts, feelings, and understandings while keeping a flexible framework as guideline. The interview guide implemented structured questions like socio-demographic issues, questions concerning the visit (e.g. length of stay), as well as the main open-ended question asking for pull and push factors. According to time constraints of visitors, interviews ranged from 7 minutes to more than 40 minutes (on average around 18 minutes). Every second interviewee was for the first time in Fulufjället. About $40 \%$ stayed only for the day, while the rest stayed on average for two days in FNP. Interviewees were also asked to fill out a self-registration card for the online survey at the park entrance, so they were represented in that part of the study as well. All conversations were recorded and held in German. Translations to English were carried out by the author afterwards. First, open coding was used to roughly identify and categorize the phenomena found in the text. After the quantitative categorization of the travel motivation, a re-reading of the interview text led to an assignment to those factors. Further, it provides data for a profound interpretation and gives hints for the improvement of REP items. 
Table 1. Description of recreation experience preference scale.

\begin{tabular}{|c|c|c|}
\hline Original domain & Description & Items \\
\hline Exploratory & $\begin{array}{l}\text { Describes the impulses to discover new territories in pristine } \\
\text { landscapes. This travel motive often pushes the extremes of } \\
\text { human travel in terms of risk and challenge }\end{array}$ & $\begin{array}{l}\text { - Experience the scenic quality of } \\
\text { nature } \\
\text { - Physical challenge } \\
\text { - Having a sense of discovery } \\
\text { - See dramatic landscapes } \\
\text { - Tranquility and peace }\end{array}$ \\
\hline Remoteness & $\begin{array}{l}\text { Is considered as a function of distance, accessibility, and the } \\
\text { restricted number of people in the area }\end{array}$ & $\begin{array}{l}\text { - Being alone/solitude } \\
\text { - Free from observation from all } \\
\text { other people } \\
\text { - Develop a sense of remoteness } \\
\text { from cities }\end{array}$ \\
\hline Simple living & $\begin{array}{l}\text { Describes the human desire for a life without daily } \\
\text { commitments, constraints, and burdens in today's society. } \\
\text { The awareness of an unhealthy lifestyle leads to the demand } \\
\text { for physical activity as well as recovery }\end{array}$ & $\begin{array}{l}\text { - Get away from daily routines } \\
\text { - Physical health and exercise } \\
\text { - Simplify daily priorities }\end{array}$ \\
\hline $\begin{array}{l}\text { Natural } \\
\text { environment }\end{array}$ & $\begin{array}{l}\text { Refers to an environment that encompasses the interaction of } \\
\text { all living species. Recreationists, voting for these items, } \\
\text { travel to experience the beauty of the ecosystem with all } \\
\text { senses }\end{array}$ & $\begin{array}{l}\text { - Enjoy outstanding views } \\
\text { - Explore the natural } \\
\text { environment } \\
\text { - Observe/hear wildlife } \\
\text { - A clean and unpolluted } \\
\text { environment } \\
\text { - Enjoy comfort in natural } \\
\text { surroundings }\end{array}$ \\
\hline Shared solitude & $\begin{array}{l}\text { Means to travel in a group that is separated from other groups } \\
\text { or people. This implies to enjoy the solitude of the } \\
\text { wilderness without disturbances of others }\end{array}$ & $\begin{array}{l}\text { - A small intimidate group } \\
\text { - Privacy from most people but } \\
\text { personal relationship } \\
\text { - Feel a special closeness with } \\
\text { others in my group } \\
\text { - Other group members were } \\
\text { accepting me for who I am }\end{array}$ \\
\hline $\begin{array}{l}\text { Connectedness/ } \\
\text { spiritual }\end{array}$ & $\begin{array}{l}\text { Is the degree that an individual includes nature as part of the } \\
\text { identity. The appreciation of the ecosystem rises while } \\
\text { feeling the spirit of nature }\end{array}$ & $\begin{array}{l}\text { - Feel connected to a place that } \\
\text { is important } \\
\text { - Recreate in a primitive } \\
\text { environment } \\
\text { - Feel a connection with others } \\
\text { who value wilderness } \\
\text { - Observe and appreciate the } \\
\text { ecosystem } \\
\text { - Obtain a deeper connection in } \\
\text { life }\end{array}$ \\
\hline $\begin{array}{l}\text { Wilderness travel } \\
\text { skills }\end{array}$ & $\begin{array}{l}\text { Wilderness skills and behaviour in nature are often neglected } \\
\text { or unknown in today's world. This refers to the ability of the } \\
\text { visitor to learn or reawake skills }\end{array}$ & $\begin{array}{l}\text { - Develop a sense of self- } \\
\text { confidence } \\
\text { - Share my skills with others }\end{array}$ \\
\hline
\end{tabular}


Table 1. Continued.

\begin{tabular}{|c|c|c|}
\hline Original domain & Description & Items \\
\hline Self-discovery & $\begin{array}{l}\text { Wilderness opens up a path leading to the inner self. Away } \\
\text { from daily life routines it is possible to rediscover the } \\
\text { purpose of life }\end{array}$ & $\begin{array}{l}\text { - Chance to think/solve } \\
\text { - } \text { problems } \\
\text { - } \text { nevelop an oneness with } \\
\text { - Get in touch with true self } \\
\text { - } \text { Opportunity for self-discovery } \\
\text { - } \text { Reflect on life } \\
\text { - Stimulate creativity }\end{array}$ \\
\hline Adventure & $\begin{array}{l}\text { Expectation that wilderness will produce a reward; the } \\
\text { adventurous experience motivates individuals to travel to } \\
\text { natural environments }\end{array}$ & $\begin{array}{l}\text { - Having an adventure } \\
\text { - To have a story to tell } \\
\text { - Experience places I have read } \\
\text { about } \\
\text { - Feel like I was the one of the } \\
\text { first people to use this place } \\
\text { - Freedom of choice as to actions } \\
\text { and use of time }\end{array}$ \\
\hline Inspiration & $\begin{array}{l}\text { Reflects the desire to find inspiration in different nature } \\
\text { sceneries. Visitors who felt inspired will enjoy the benefit } \\
\text { also during daily life }\end{array}$ & $\begin{array}{l}\text { - Experience nature's magic and } \\
\text { mysticism } \\
\text { - Find inspiration in natural } \\
\text { surroundings }\end{array}$ \\
\hline
\end{tabular}

\section{Data analysis}

Statistical techniques used range from simple descriptive statistics to reliability analysis and exploratory factor analysis. A reliability analysis examines the internal consistency of the previous domains and the extracted factors. A Cronbach alpha of above .60 is considered as an acceptable range of internal consistency (Cortina, 1993; Nunnally, 1978). An item-total correlation test $(<.30)$ was performed to check if an item in the set varies from the averaged behaviour of the others and can be rejected (Field, 2005).

The exploratory factor analysis was conducted to establish factors between the measured variables based on Bartlett's sphericity and the Kaiser-Meyer-Olkin (KMO) test (Kaiser, 1970). A Scree test determined the number of factors (Cattell, 1966). Items with low communality $(<.40)$ and cross-loading items with a high loading (>.32) on two or more factors were excluded (Costello \& Osborne, 2005). Computed factor scores were used in subsequent analyses. All data analyses were conducted using the Statistical Package for the Social Sciences (SPSS).

\section{Results}

\section{Profile of the German visitor}

As predicted, there is a relatively high proportion of international visitors in FNP. More than one-third of all visitors were from abroad. The statistics show that Germans were the largest foreign group (17.7\%), followed by the Dutch (4.5\%) and Danes (3.8\%).

A profile of the German FNP visitor in contrast to the average FNP visitor shows some distinctive features. The mean age of German visitors is 44 years, which is 5 years less compared 
with all visitors (49 years). Just like the visitors from other nationalities, nearly every German travelled to FNP by private means (96\%) and with the family (70\%). Germans stayed on average longer in FNP (2-3 days) and the activity spectrum was wider and more intensive. Thus, the day-long hike was marked as the most important activity by $35 \%$ of the Germans, followed by a short walk (30\%), and a hike for several days (18\%). The activity profile of these visitors also displays an outstanding preference of nature photography (70\%). Other activities were picking berries (22\%), and nature study/bird watching (19\%). Another significant difference is that Germans were more spread over the area and about one of three visited the wilderness zone. But the most frequent visited zone was number four (91\%) which has the Njupeskär waterfall. It is noticeable that the overall satisfaction is very high among Germans $-44 \%$ were completely satisfied, and $52 \%$ were satisfied with their visit in FNP. There were also a large number of repeated visitors (32\%). Hence, these facts are a first indication of a possible fulfilment of motivational incentives.

\section{Motivational classes}

Next, looking at the motivations to visit FNP among the German visitors, a reliability analysis revealed that all original chosen domains had acceptable internal consistencies (>.60), but the examination of the corrected item-total correlations revealed two items ("enjoy comfort in natural surroundings" and "physical challenge") with an insufficient acceptable level of internal stability. These items were not used for further analysis. Moreover, statistics presented a "meritorious" KMO index (>.8) according to Kaiser and Rice (1974), which indicates that variables are measuring a common factor. The analysis of the antiimage correlation matrix also supported the use of a factor analysis and suggested a grouping into a smaller set of underlying factors. Three variables ("freedom of choice as to actions and use of time", "to have a story to tell", and "experience places I have read about") had to be deleted because of cross-loadings and an inappropriate internal consistency within the revealed factors. Hence, five factors out of 10 domains were able to represent appropriate relations between the test variables (Table 2 ).

The final rotated component matrix shows that the first component explains $34.5 \%$, while the second explains $10.6 \%$ of the variance. All reliability coefficients have acceptable internal consistencies. The boxplot visualizes the distribution of the level of importance on a converted scale from 0 (not at all important) to 4 (extremely important) (Figure 2).

Factor (2) was highly appreciated by German tourists. Thus, nature had the highest median (2.33) and 50\% of the data had a higher importance than "moderate". Visitors had also the highest agreement among themselves (inter quartile range $(I Q R)=1.22$ ). Factor 5 shows similar results, while factor 3 seems to build the medium category with no outstanding position. In contrast, the self-related factor 1 plays a subordinate role within the travel decision of German visitors. Nearly half of all visitors assessed this factor with the category "slightly important". Social factor 4 shows a similar picture, but the IQR reveals the highest range (1.5). People agree less consistently with the social motives than with the self-related motives.

\section{Interpretation of motivational classes}

The first revealed factor "Focus on Self - Introspection" describes the nature of FNP as an instrument to obtain psychological outcomes. It is the degree to which the elements of the 
Table 2. Reliability analyses of determined factors.

\begin{tabular}{|c|c|c|c|c|c|}
\hline Domains and corresponding Items ${ }^{a}$ & $\begin{array}{l}\text { Item-total } \\
\text { correlation }\end{array}$ & $\begin{array}{c}\text { Cronbach's alpha if item } \\
\text { deleted }\end{array}$ & $\begin{array}{l}\text { Cronbach's } \\
\text { alpha }\end{array}$ & M & SD \\
\hline 1. Focus on self - introspection & & & .913 & 1.20 & .94 \\
\hline Reflect on life & .832 & .894 & & & \\
\hline Obtain a deeper connection in life & .750 & .899 & & & \\
\hline Opportunity for self-discovery & .825 & .893 & & & \\
\hline Get in touch with true self & .790 & .896 & & & \\
\hline Find inspiration in natural surroundings & .689 & .904 & & & \\
\hline Chance to think/solve problems & .645 & .906 & & & \\
\hline Stimulate creativity & .672 & .905 & & & \\
\hline Develop a sense of self-confidence & .588 & .911 & & & \\
\hline $\begin{array}{l}\text { Feel like I was the one of the first people to } \\
\text { use this place }\end{array}$ & .475 & .916 & & & \\
\hline 2. Focus on nature - awareness and sensation & & & .868 & 2.90 & .71 \\
\hline Recreate in a primitive environment & .700 & .846 & & & \\
\hline Observe and appreciate the ecosystem & .718 & .843 & & & \\
\hline A clean and unpolluted environment & .660 & .853 & & & \\
\hline Explore the natural environment & .686 & .850 & & & \\
\hline Experience nature's magic and mysticism & .597 & .856 & & & \\
\hline Develop a oneness with nature & .694 & .845 & & & \\
\hline Observe/hear wildlife & .556 & .859 & & & \\
\hline Experience the scenic quality of nature & .449 & .868 & & & \\
\hline Feel connected to a place that is important & .524 & .866 & & & \\
\hline 3. Focus on freedom - escape and balance & & & .858 & 2.48 & .89 \\
\hline Develop a sense of remoteness from cities & .776 & .814 & & & \\
\hline Being alone/solitude & .716 & .824 & & & \\
\hline $\begin{array}{l}\text { Free from observation from all other } \\
\text { people }\end{array}$ & .591 & .844 & & & \\
\hline Get away from daily routines & .728 & .822 & & & \\
\hline Tranquility and peace & .629 & .840 & & & \\
\hline Simplify daily priorities & .489 & .858 & & & \\
\hline Physical health/and exercise & .466 & .858 & & & \\
\hline 4. Focus on others - relationships & & & .831 & 1.30 & .99 \\
\hline $\begin{array}{l}\text { Feel a special closeness with others in my } \\
\text { group }\end{array}$ & .744 & .774 & & & \\
\hline $\begin{array}{l}\text { Other group members were accepting me } \\
\text { for who I am }\end{array}$ & .704 & .781 & & & \\
\hline A small intimidate group & .530 & .818 & & & \\
\hline $\begin{array}{l}\text { Privacy from most people but personal } \\
\text { relationship }\end{array}$ & .509 & .823 & & & \\
\hline Share my skills with others & .630 & .801 & & & \\
\hline $\begin{array}{l}\text { Feel a connection with others who value } \\
\text { wilderness }\end{array}$ & .528 & .820 & & & \\
\hline 5. Focus on experiences - exciting setting & & & .740 & 2.89 & .75 \\
\hline See dramatic landscapes & .599 & .644 & & & \\
\hline Having a sense of discovery & .641 & .633 & & & \\
\hline Enjoy outstanding views & .486 & .707 & & & \\
\hline Having an adventure & .475 & .746 & & & \\
\hline
\end{tabular}

Items were coded on a 5-point Likert scale, with the response categories 1, not at all important, to 5, extremely important, $N=184$.

experience are internalized, a reflective thought process where the development of immediate solutions should be sought. Recreation and leisure are considered to be the ideal situations in which identities can be confirmed (Borrie \& Birzell, 2001). Kaplan and Kaplan (1989) found that contact with nature or elements of nature has a positive effect on the human mind and life quality. Experiences in wilderness settings also seem to be more intensive than that in other settings, for example local recreational areas (Chang, Hammitt, Chen, Machnik, \& Su, 2008). Cole (2010) found that even a few hours spent in wilderness are sufficient for substantial stress reduction and mental rejuvenation. 


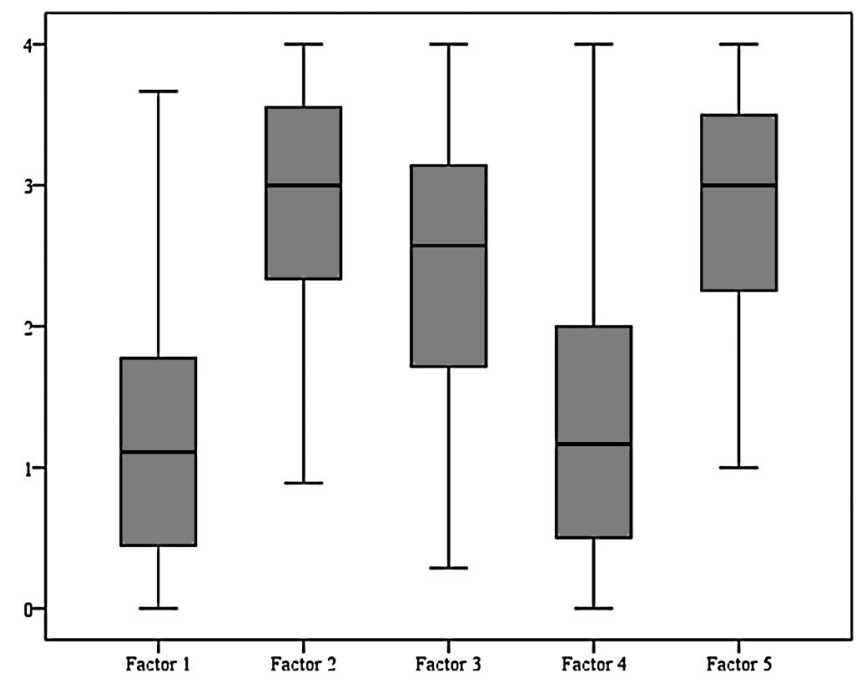

Figure 2. Level of importance for determined factors. Converted 5-point Likert-type scale with the response categories from 0 , not at all important, to 4 , extremely important.

However, the survey results only partly prove FNP's ability to increase the mental wellbeing among visitors. A closer look at the conducted activities reveals that visitors with a high appreciation of factor 1 preferred to hike for several days rather than for a few hours only. Thus, a long hiking trip seems to be more suitable to satisfy these motives. The introspection factor was also brought up in the qualitative interviews. In this context, a 48 years old father from Cologne stated, "It is an experience you cannot find somewhere else. Such a unique experience that is not available in normal life, in a town or a park". Further, a 70 years old woman reported:

To be active in the natural environment is simply restorative. And of course, one can find inner peace. When a human goes to the loneliness he always gains a benefit. That is an individual benefit for the soul and the spirit. This stands also behind $[\ldots]$ behind wilderness.

The second factor "Focus on Nature - Awareness and Sensation" proposes rewards associated with the aesthetical experience (scenery, symbolic qualities, and other valued attributes) found in the natural environment. There is a commonality with factor 1, but factor 2 reflects more the enjoyment of the biophysical environment rather than the emotional experiences from it. As a result, visitors may become attached to a certain type of landscape by developing meanings, feelings, and subjective perceptions (Borrie \& Birzell, 2001).

Survey results show a high importance of this factor not only in general, but also more specifically among the respondents to the qualitative interviews. Overall, a closer look at the item constellation reveals that experiencing the scenic quality of nature had the highest single meaning among all items; about nine of 10 Germans ranked this item as extremely important followed by a clean and unpolluted environment, which had the second highest ranking. Visitors felt less attracted by attributes like outstanding and spectacular (factor 5); it is much more the experience of nature's quality (naturalness, unspoiled, and primitive state) that counts. 
The on-site interviews were also comparable with the quantitative survey results in this respect. Nearly all interviewees mentioned the quality of nature in some way. "Magnificent", "beautiful", "natural", and "magical" are all examples of quality determining descriptions of FNP. Such interpretations are of course in the hand of each individual, but it is obvious that FNP offers highly contrasting landscapes to Germany. The desire to discover this setting can be seen as one possible expression of deficiency in one's home environment. Interviewees expressed the outstanding position of the setting, "Here nature is still nature - primordial nature", "Nature is original and unaffected. The landscape is still open" and "Experiencing nature is something different here. You do not have this type of nature all the time around you". The geographical location and accessibility are also seen as crucial advantages of FNP. On the one hand, the area lies on the passage to Norway and on the other hand, it is one of the first possibilities to see the fjäll as a typical and famous type of Swedish landscape travelling north from Germany. It is likely that frequent visitors developed a feeling of familiarity to Sweden. A couple even "found" a second home in the FNP Mountains, "That may sound hypothetical and exaggerated, but I feel like coming home." A 77 years old man expressed his feelings towards the travel destination, "We are here every year, for centuries. We speak Swedish ( ... ) we inhale it like the air we breathe." A couple from south of Germany even reported that they are infected by the "Scandinavian fever". Visitors also developed high expectations to spot wildlife during their holiday stay, "For nearly 40 years we drive to Scandinavia, but we had seldom seen moose - maybe 10 times. But thank goodness, we have seen renders this year." It is noticeable that the actual product of the observation is a kind of holistic experience. In this case the setting of the encounter does not matter so much to the visitor; it is the sensual experience, the feeling of a connection to a greater whole.

The factor "Focus on Freedom - Escape and Balance" places value on wilderness experience because it allows one to escape from problems associated with urban living or daily work life. Nowadays, people have to face a number of stressors like personal, organizational, societal, and environmental factors that may lead to physiological or psychological discomfort and in some cases even illness (Steg, Berg v.d., \& de Groot, 2012; Stokols \& Altman, 1987). A natural area like FNP provides a setting without many of the exposures to challenging stressors, and the Right of Public Access allows for a feeling of liberty while roaming in the Scandinavian landscape.

The data show that gaining physical health through exercise in a tranquil and remote area is an important motive for this category. Another noticeable feature was that visitors valued the item "being alone" relatively high, while only $5 \%$ was completely unaccompanied during the visit at FNP. Thus, solitude should be more understood in the context of a shared solitude, being away from home, and enjoying a transitional isolation from social structures. A prerequisite for this process is privacy. However, data show that $63 \%$ of the Germans actually felt disturbed to a certain degree.

Especially the long-time hiking tour is a suitable instrument for the profound purpose of this factor. The natural and/or adventurous setting (factors 2 and 5) is rather seen as peripheral and visitors were mainly concentrated on struggle or involvement in the task.

Interviews are able to also support these findings. A 67 years old man stated, "Our three most important reasons for visiting Fulufjället? That is simple: tranquility, being without stress, and remoteness." The mobile phone seems to be one last remaining indicator of the daily life. Some interviewees refused the unpleasant "souvenir from home" with the 
expectation to slow down life. It is well known that remote areas are often appreciated in more urbanized countries for providing a contrast to the stress of urban life. A visitor from the metropolis of Hamburg expressed his feelings, "It was spontaneous ( ... ) maybe an anti-civilization impulse! We wanted to go to a place where it is not crowded and where we find less settlement. Actually, we wanted to relax [...] being absolutely away." But some visitors also felt disturbed during the visit to FNP. The trails often get congested, particularly close to the facilities and the main attraction, Njupeskär. An experience of crowding may lead to spillover effects such as stress, conflicts, and/or complaints. Thus, interviewees clearly defined the wilderness borders as "everything except from the Njupeskär trail". But the statements also indicate that these visitors were successful in seeking alternatives (off-season visit, change of zone/setting). Apparently, the sense of place is stronger than the disturbance factor.

The factor "Focus on Others - Relationships" focuses primarily on the multifaceted social experiences in a wilderness area. Concerns about presence (or absence) and responses to other people like friends, family, strangers, and the general public shape the meanings in this context (Borrie \& Roggenbuck, 2001).

Items of this factor were considered rather unimportant except for the item "privacy from most people but personal relationships". This is consistent with the fact that almost all visitors came to FNP on a private trip. Even if the family played a major part during the FNP visit and the stay with friends was over-represented, there was no incentive to increase the group cohesion. Only long-time hikers were slightly more influenced by motives of this factor.

During the interviews, visitors highlighted that they prefer to travel privately and not in organized groups. They emphasized to be "total individualists". It may be the reason why building up new relationships and sharing skills were less important. It is more the isolation from others and the enjoyment of a shared solitude that count (factor 3). In some exceptional cases was the transfer of knowledge a reason to visit the unknown terrain, "We wanted to show it to our children, at least once in a lifetime $(\ldots)$ this type of tundra zone with the berries and the renders. It was amazing to see some!"

According to the last factor "Focus on Experiences - Exciting Setting", FNP is seen as an arena for action and adventure. From the viewpoint of the participant, the scenery with its features is only one aspect of a complex environmental experience (Ittelson, 1978). Hågvar (1999) argued that humans love to be fascinated, to observe unexpected phenomena and processes, and to think about possible explanations. Hence, a collection of unexplained wonders in nature seems to be like a "mental harvest". Kaplan and Kaplan (1989) even pointed out that the curiosity of exploring the environment could be understood as a basic human need. The landscapes of FNP are contrasting and diverse, including the plateau, belt of spruce trees around, old pine trees, peat bog areas, as well as the coverage with lichens and mosses. But also the main attraction Njupeskär has a large audience. The survey results showed that particularly "seeing dramatic landscapes" and "enjoying outstanding views" were the most important motives. One-day hikers valued this class above the average.

The interpretation of these items is a wide spectrum of alternatives. Interviewees often mentioned the exploration of the typical landscape type fjäll as an incentive to visit FNP. But visitors also listed more individual preferences, "getting to know new plants", "animals", or just the "ecosystem" as a whole. A central element of the visit is the learning 
dimension. Increasing the knowledge about the park in the first language (via brochures, information boards, and guided tours) is appreciated. One interviewee stated, "It is nice to have some information along the trails about things you would not discover on a first glance for example formations of trees." But to discover nature's mystery and unfamiliar landscapes and to explore hidden information may also be seen as a challenge where individuals test their physical abilities. Features of modernity and security, like mobile networks, are not demanded. This condition seems to be a certain appeal of the wilderness experience, "They have no mobile network up there. But they know it and that is actually what they want." However, Germans in FNP do not specifically seek a risk or challenge in wilderness. Some security tools concerning infrastructure, management, and service quality are demanded. A clearly signposted hiking trail network, tourism infrastructure (visitor centre, campground, and food facilities), and the closeness to areas of local supply are regarded beneficial. Overall, this guarantees a certain feeling of safety even when being in a wilderness.

\section{Discussion}

The mixed-method approach applied in this study was useful to demonstrate how the travel motivation of German visitors to FNP is constructed. The quantitative analysis allowed identifying five possible motivational groups. The factor "Focus on Nature Awareness \& Sensation" had the highest mean agreement followed by "Focus on Experiences - Exciting Setting". Rather unimportant were "Focus on Others - Relationships" and "Focus on Self - Introspection". "Focus on Freedom - Escape \& Balance" seems to build a medium category.

Previous research has shown that experiencing nature is a main travel motive among visitors of Scandinavia (Gössling \& Hultman, 2006) and comparable studies have identified a similar motivation pattern. Raadik et al. (2010) identified the category "Experience of Places" as one possible factor among all FNP visitors and "Sightseeing" was found to be a travel motive among international motor tourists in Norway (Haukeland et al., 2010). Research has also shown that nature is seen as a romanticized playground in which the visitor is embedded in a passive process of being engaged (Gössling \& Hultman, 2006; Hultman \& Cederholm Andersson, 2006). The involvement of a primitive environment (wilderness setting) enables visitors to find rewards unobtainable in civilized settings. This finding is in line with German travel market research where get-away motives are well known to overbalance the travel motive ranking (Laßberg \& Steinmassl, 1991).

Through the quantitative study, it was demonstrated that travel motivation could be identified as patterns and combinations of multiple motives that are influenced by previous travel experiences and activities. It is noticeable that the determined motivational factors show interrelations and interdependencies and that "push" and "pull" travel motives work in tandem. For example, follow-up visitors felt less attracted by the highlighting attributes like "outstanding" and "spectacular"; it is more the quality of nature (naturalness, unspoiled, and primitive state) that counts. Furthermore, short-time hikers and long-time hikers had a reversed motivational profile. The aesthetical value of nature seems to be the main attracting factor for short-time hikers, while a hiking tour of several days is the crucial instrument for the profound purpose of temporal escape from home with an inner reflection and social cohesion in mind. Hence, there is evidence 
that attendants of a long-time hiker have a slightly higher tendency to represent a "harder" type of eco-tourist who is characterized by being more physically active, searching deep relations with nature, looking for more physical challenges, and expecting few if any facilities (Weaver, 2008). The transfer of these findings to tourism planning and management activities is highly relevant, especially for unspoiled destinations (Sæpórsdóttir, 2010).

From the quantitative data, it is obvious that the experience and exploration of a natural and pure environment with an outstanding scenic quality determined the visitors' travel decision. But through analysing the qualitative interviews, it is evident that exploration should not be interpreted in the sense of discovery. Exploration should be understood in a rather passive way of experiencing FNP's outstanding views, natural attractions and the biota. Game watching belongs to nearly 9 of 10 Germans to a true wilderness experience and activated a profound reflection during the interviews. The perception of nature with all senses leads in effect to the development of particular emotional attachments in the form of sense of place (see the meaning-based approach by Borrie \& Birzell, 2001). A high rate of follow-up visits proves the bonding force of FNP. Moreover, Germans feel addressed through the relative secure environment during their visit. Overall, tourists do not seek to interact with nature in terms of experiencing risks and challenges. Certain basic infrastructures like cabins for rest, a marked trail network, and a national park centre as a major information source are demanded. The reported importance concerning the infrastructure facilities along with the ROS planning system is also confirmed. Germans are more spread over the area and appreciate possibilities to enjoy a shared solitude, but privacy throughout the park's zones. A hiking tour with moderate involvement is a valued form to satisfy the needs. An inner reflection was not an apparent reason, but an unconscious reflection that cannot be excluded. Furthermore, the high degree of individually organized journeys may be one reason for a low assessment of the social factor.

It is obvious that FNP's scenery, and in particular the wilderness characteristics of the area, has a unique instrumental significance in times of ongoing population growth, increasing land use, and continuous environmental pollution that many parts of Central European countries face today. Especially in Germany, wilderness areas are very rare and, therefore, the instrumental potential for values such as those studied here is highly reduced. Recent studies also found that Germans wish to have access to and experience more wildernesses (BfN, 2013), but the dominance of cultural landscapes only allows a few places to represent wilderness in the sense of the International Union for Conservaion of Nature and Natural Resources (2013).

\section{Limitations and future research}

Before considering any further implications of the results, it is important to reconsider the study limitations, some of which could influence the scope to which the results are applicable. Findings of this exploratory study were also rather comprehensive and there are still unanswered issues giving room for future research. The mixed-method approach, supplementing the quantitative results with in-depth interviews, provides a much more informative examination than a quantitative analysis alone does. But according to a relatively small sample size ( $N=184)$ and the study's complexity, an approach of a larger scale is recommendable to provide better representativeness. The investigation of other Scandinavian National Parks and a long-time monitoring of FNP visitors provide evidence about the 
study's validity, supported by the comprehensive questionnaire which draws from earlier research in the area (Fredman et al., 2007; Raadik et al., 2010). But as the quantitative and qualitative research were conducted simultaneously, the design followed a triangulation approach, rather than a complementary or development design. Nevertheless, the presented REP scales (Table 2) are tested to be valid and recommendable for further research in FNP and in other Scandinavian National Parks. A suggestion for future studies could then be to use additional interviews for the expansion of the REP scales. Germans put a high focus on the cognitive component and were pleased to find information material in their language. Therefore, "generating knowledge in your own language" could be a suitable item to determine the importance via a qualitative ranking. Concerning the infrastructure and management quality, it was evident that security during the visit is appreciated. Thus, "obtain the feeling to be secure in wilderness" is a possible description for an additional motive in future REP scales. Additional items specific to FNP are "seeing another landscape type (fjäll)", "obtain a feeling of freedom", "roam free in the landscape", and "seeing incomparable and spectacular attractions" (relating to Njupeskär). Further, Germans showed a very high agreement with the item "experience the scenic quality of nature". The understanding of the aesthetical perception of nature among Germans could be improved through additional qualitative research. Moreover, "get away" motives have often a high personal connotation and in-depth interview techniques may allow a closer examination of this category. A qualitative survey among different zone users and a closer examination of the activity spectrum would also allow us to more clearly see the boundaries between factors.

\section{Conclusions and implications}

With the above-mentioned limitations in mind, the study still provides many important marketing and management implications with a potential value to public sector managers and business decision-makers, as well as the tourists themselves (Pearce, 2005).

On the one hand, an understanding of motives, as initiators of the travel decision process, builds the key to successful business activities because industry practitioners will be able to offer more customized and memorable products (Huang \& Hsu, 2009). Factors with a high meaning for Germans visiting FNP were mainly "pull" factors. Thus, there is a potential to coordinate marketing activities to identified items of nature (factor 2) and experiences (factor 5). A closer look at the advertising by tourism stakeholders allows a comparison between measured on-site motives and advertised messages. An example is provided by the Swedish National Tourist Board that promotes Swedish nature with the terms naturalness, accessibility, and exploration (Visit Sweden, 2015). It awakes the desire to discover the "last remaining wilderness hotspots" in Europe. Especially FNP is highlighted by the advantage of all-season nature adventure and experiences. Regarding this study, it seems that Germans who valued the experiences of factor 5 should feel highly addressed. This is especially valid for one-day hikers.

The "call of the wild" seems to be an effective marketing slogan of German tourist operators. But the study indicates that the influence of wilderness could not be referred to the spatial distribution of the tourists. Various people may feel attracted by this item: from a Njupeskär visitor in the front-country region to a hiker who stayed overnight on the plateau in the back-country part of the park. The term wilderness thereby needs to be 
specified for target group-orientated marketing activities as the spectrum of understanding appears to be pretty wide. Especially long-time hikers would feel addressed by the promotion of temporal isolation and anti-civilizing features. In this sense, the "call of the wild" may be interpreted as the demand for a natural and remote setting, an antithesis to the existing world that promises to provide the feeling of freedom. In general, it is not recommendable to use items of the determined introspection or social factors for marketing purposes. Especially, problem-orientated motives like "having a chance to think" or "solve problems" were not evident in this study. But it is obvious that marketing which addresses different target groups should take such divergences into account.

The promotion of protected areas as tourist destinations has also brought increased impacts with it and agencies are increasingly being faced with visitor management issues (Eagles, 2014). Having knowledge about the visitors is, therefore, important for shaping expectations and for directing users to appropriate parks or places. Tourism, especially in FNP, is highly dependent upon the quality of the environment. About nine of 10 visitors were mainly driven by the idea to explore the scenic quality of nature. Thus, it can be affirmed that the protection status should be maintained to ensure these values. But the second issue is more challenging as it cannot be generalized; it is the maintenance of the recreational experience quality for the tourists themselves. Key factors which may affect the quality of the experience include the number and type of other users encountered, as well as the expectations, preferences, and experiences of the users themselves (Boyd \& Butler, 1996).

Within the context of ecotourism growth and the increasing demand for recreation, a number of visitor management frameworks and procedures have been developed over the past decades. Study results indicate that people are sensitive towards crowding within the zoning system at FNP, and some respondents even defined wilderness as "everything despite of the Njupeskär trail" (located in zone 4). The wider area was frequented by long-time hikers who valued the factor "Focus on Freedom - Escape and Balance" above the average. Thus, related motives need to be guaranteed in the rather undisturbed zone. Another issue that should get attention in management plans is waste disposal as Germans want to experience a clean and unpolluted environment. Hence, the zone system with its permissions and restrictions should be communicated frequently with the visitors to FNP, and a systematic monitoring scheme would allow for screening whether management actions have desired effects (Eagles, 2014).

Besides the maintenance of recreational opportunities in agreement with the protection principles, it is also beneficial to communicate FNP's values more intensively. The significance of Njupeskär as the main visitor attraction is uncontroversial. But as Germans were generally more spread over the area, there seems to be a strong interest to discover additional features of the national park well beyond the more developed parts. However, FNP is still an insider tip among Germans and managers should pay more attention to this. Added values (activities, guided tours, and events) need to be both implemented and communicated, mainly during the pre-visit phase. If visitors were to spend more time in the area, it will likely contribute to revenues for the nearby communities and intertwined tourism businesses.

\section{Disclosure statement}

No potential conflict of interest was reported by the authors. 


\section{Funding}

This work was supported by Swedish Environmental Protection Agency.

\section{References}

Arthur, G. (2008). Die Unschuld Schwedens. NORR. Das Skandinavien Magazin, 3, 20-24.

Balmford, A., Green, J. M. H., Anderson, M., Beresford, J., Huang, C., Naidoo, R., ... Manica, A. (2015). Walk on the wild side: Estimating the global magnitude of visits to protected areas. PLOS Biology, 13(2), e1002074. doi:10.1371/journal.pbio.1002074

B.A.T. - Stiftung für Zukunftsfragen; Freizeit- und Forschungsinstitut. (2006). Wachsende Reiselust. Urlaube werden wieder länger. Trend zu immer kürzer werdenden Reisen gestoppt. 189. Retrieved January 11, 2015, from http://www.stiftungfuerzukunftsfragen.de/newsletterforschung-aktuell/189.html

BfN - Bundesamt für Naturschutz. (2013). Naturbewusstseinsstudie. Bevölkerungsumfrage zu Natur und biologischer Vielfalt. Retrieved October 1, 2014, from http://www.bfn.de/0309_naturbewusstsein.html

Borrie, W. T., \& Birzell, R. M. (2001). Approaches to measuring quality of the wilderness experience. In: Freimund, W. A., Cole, D. N., comps. Visitor use density and wilderness experience: Proceedings; 2000 June 13; Missoula, MT. Proceedings RMRS-P-20. Ogden, UT: U.S. Department of Agriculture, Forest Service, Rocky Mountain Research Station: 29-38.

Borrie, W. T., \& Roggenbuck, J. W. (2001). The dynamic emergent and multi-phasic nature of on-site wilderness experiences. Journal of Leisure Research, 33(2), 202-228.

Boyd, S. W., \& Butler, R. W. (1996). Managing ecotourism. An opportunity spectrum approach. Tourism Management, 17(8), 557-566.

Bushell, R., \& Eagles, P. J. (2007). Tourism and protected areas: Benefits beyond boundaries. Wallingford: CABI.

Cattell, R. B. (1966). The Scree test for the number of factors. Multivariate Behavioral Research, 1, 245-276.

Chang, C., Hammitt, W. E., Chen, P., Machnik, L., \& Su, W. (2008). Psychophysiological responses and restorative values of natural environments in Taiwan. Landscape and Urban Planning, 85, 79-84.

Cole, D. N. (2010). Experiencing the restorative components of wilderness environments. Does congestion interfere and does length of exposure matter? Environment and Behavior, 42(6), 806-823.

Cooper, C., Fletcher, J., Gilbert, D., \& Wanhill, S. (2008). Tourism principles and practice. Harlow: Pearson Education.

Cortina, J. M. (1993). What is coefficient alpha? An examination of theory and applications. Journal of Applied Psychology, 78(1), 98-104.

Costello, A. B., \& Osborne, J. W. (2005). Exploratory factor analysis. Four recommendations for getting the most from your analysis. Practical Assessment, Research, and Evaluation, 10(7), 1-9.

Crompton, J. (1979). Motivations of pleasure vacations. Annals of Tourism Research, 6(4): 408-424.

Dann, G. M. S. (1981). Tourist motivation an appraisal. Annals of Tourism Research, 8, 187-219.

Driver, B. L. (1983). Master list of items for Recreation Experience Preference scales and domains. Unpublished document. USDA Forest Service. Fort Collins, CO: Mountain Forest and Range Experiment Station.

Driver, B. L., \& Brown, P. J. (1975). A sociopsychological definition of recreation demand with implications for recreation resource planning. In Assessing demand for outdoor recreation (pp. 62-68). Washington, DC: National Academy of Sciences.

Driver, B. L., Brown, P. J., Gregoire, T. G., \& Stankey, G. H. (1987). The ROS planning system. Evolution and basic concepts. Leisure Sciences, 9, 201-212.

Eagles, P. (2014). Research priorities in park tourism. Journal of Sustainable Tourism, 22(4): 528-549.

Eagles, P. F. J., McCool, S. F., \& Haynes, C. D. (2002). Sustainable tourism in protected areas guidelines for planning and management. Ed Adrian Phillips. IUCN, Gland, Switzerland and Cambridge, UK.

Field, A. P. (2005). Discovering statistics using SPSS (2nd ed.). London: Sage.

Fredman, P., \& Heberlein, T. (2005). Visits to the Swedish mountains: Constraints and motivations. Scandinavian Journal of Hospitality and Tourism, 5(3), 177-192. 
Fredman, P., Hörnsten Friberg, L., \& Emmelin, L. (2005). Friluftsliv och turism i Fulufjället - Före-efter nationalparksbildningen: Dokumentation av de svenska nationalparkerna $\mathrm{nr}$ 18. Stockholm: Naturvårdsverket (Rapport / Naturvårdsverket 5467).

Fredman, P., Hörnsten Friberg, L., \& Emmelin, L. (2007). Increased visitation from national park designation. Current Issues in Tourism, 10(1), 87-95.

Fredman, P., \& Wikström, D. (2015). Besök och besökare i Fulufjällets nationalpark sommaren 2014 (med jämförelser åren 2001 och 2003). Mid-Sweden University, ETOUR, rapport 2015: 5.

F.U.R. - Forschungsgemeinschaft Urlaub und Reisen e.V. (2014). Abschlussbericht zu dem Forschungsvorhaben: Nachfrage für Nachhaltigen Tourismus im Rahmen der Reiseanalyse. Kiel. Retrieved September 1, 2014, from http://www.fur.de/fileadmin/user_upload/externe_Inhalte/ Publikationen/20140912_RA14_BMU_Nachhaltige-Nachfrage_Bericht.pdf

Goossens, C. (2000). Tourism information and pleasure motivation. Annals of Tourism Research, 27(2), 301-321.

Gössling, S., \& Hultman, J. (2006). Ecotourism in Scandinavia. Lessons in theory and practice. Wallingford: $C A B I$.

Graefe, A. R., Thapa, B., Confer, J. J., \& Absher, J. D. (2000). Relationships between trip motivations and selected variables among Allegheny national forest visitors. Proceedings - Rocky Mountain Research Station, USDA Forest Service 2000 No. RMRS-P-15(4): 107-112.

Haukeland, J. V., Grue, B., \& Veisten, K. (2010). Turning national parks into tourist attractions. Nature orientation and quest for facilities Scandinavian. Journal of Hospitality and Tourism, 10(3), 248-271.

Hågvar, S. (1999). Nature as an arena for the quality of life: Psycho-spiritual values - The next main focus in nature conservation? The Environmentalist, 19, 163-169.

Huang, S. S., \& Hsu, C. H. C. (2009). Travel motivation, linking theory to practice. International Journal of Culture, Tourism and Hospitality Research, 3(4), 287-295.

Hultman, J., \& Cederholm Andersson, E. (2006). The role of nature in Swedish ecotourism. In S. Gössling, \& J. Hultman (Eds.), Ecotourism in Scandinavia. Lessons in theory and practice (pp. 7688). Wallingford: $C A B I$.

IBIS - Tillväxtverket. (2013). Results from the Swedish Border Survey. IBIS 2013. Foreign visitors in Sweden. Retrieved January 29, 2015, from http://www.tillvaxtverket.se/sidhuvud/englishpages/ tourismindustryissuesandstatistics/swedishbordersurveyibis/ibis20112013.4. b5c1e11460ef4bead2eeb6.html

Iso-Ahola, S. E. (1982). Toward a social psychological theory of tourism motivation. A rejoinder. Annals of Tourism Research, 9(2), 256-262.

Ittelson, W. H. (1978). Environmental perception and urban experience. Environment and Behavior, 10, 193-213.

IUCN - International Union for Conservaion of Nature and Natural Resources. (2013). Guidelines for applying protected area management categories. Gland. Retrieved October 3, 2014, from http:// www.iucn.org/about/work/programmes/gpap_home/gpap_capacity2/gpap_pub/gpap_catpub/? 13959/Guidelines-for-applying-protected-area-management-categories

Kaiser, H. F. (1970). A second generation Little Jiffy. Psychometrika, 35, 401-415.

Kaiser, H. F. \& Rice, J. (1974). Little Jiffy, mark iv. Educational and Psychological Measurement, 34(1), $111-117$.

Kaplan, R., \& Kaplan, S. (1989). The experience of nature. A psychological perspective. New York: Cambridge University Press.

Knoller, R. (2014). Nordeuropa. Porträt einer Region. Berlin: Christoph Links Verlag.

Laßberg, D. V., \& Steinmassl, C. (1991). Urlaubsreisen 1990. Kurzfassung der Reiseanalyse 1990. Starnberg: Studienkreis für Tourismus.

Manfredo, M. J., \& Driver, B. L. (1996). Measuring leisure motivation. A meta-analysis of the recreation experience preference scales. Journal of Leisure Research, 28(3), 188.

Manning, R. E. (1999). Studies in outdoor recreation. Search and research for satisfaction (2nd ed.). Corvallis: Oregon State University Press.

Manning, R. E. (2012). Managing outdoor recreation. Case studies in the national parks. Cambridge: CABI. 
Mansfeld, Y. (1992). From motivation to actual travel. Annals of Tourism Research, 19(3): 399-419.

Mehmetoglu, M. (2007). Nature-based tourists: The relationship between their trip expenditures and activities. Journal of Sustainable Tourism, 15(2), 200-215.

Molina-Azorín, J. F., \& Font, X. (2015). Mixed methods in sustainable tourism research: An analysis of prevalence, designs and application in JOST (2005-2014). Journal of Sustainable Tourism. doi:10. 1080/09669582.2015.1073739

Mose, I. (Ed.). (2007). Protected areas and regional development in Europe. Towards a new model for the 21st century. Aldershot: Ashgate.

Mundt, J. W. (2013). Tourismus (4th ed.). München: Oldenbourg.

Newman, P., \& Dawson, C. D. (1998). The human dimensions of the wilderness experience in the High Peaks Wilderness Area. Proceedings of the 1998 Northeastern Recreation Research Symposium. April 5-7, 1998, 122-129.

Nunnally, J. C. (1978). Validity. In Wright and Gardner (Eds.), Psychometric theory (p. 701). New York, NY: McGraw-Hill.

Pearce, P. L. (2005). Tourist behaviour: Themes and conceptual schemes. Clevedon: Channel View.

Pearce, P. L., Morrison, A. M., \& Rutledge, J. L. (1998). Tourism. Bridges across continents. Sydney: McGraw-Hill.

Puhakka, R., Cottrell, S. P., \& Siikamäki, P. A. (2013). Sustainability perspectives on Oulanka National Park, Finland: Mixed methods in tourism research. Journal of Sustainable Tourism, 22(3), 480-505.

Raadik, J., Cottrell, S. P., Fredman, P., Ritter, P., \& Newman, P. (2010). Understanding recreational experience preferences. Application at Fulufjället National Park, Sweden. Scandinavian Journal of Hospitality and Tourism, 10(3): 231-247.

Roggenbuck, J. R., \& Driver, B. L. (2000). Benefits of nonfacilitated uses of wilderness. pp. 33-49. In: Wilderness Science in a Time of Change Conference. Volume 3: Wilderness as a place for scientific inquiry. Proceedings RMRS-P-15-VOL-3. USDA Forest Service. Rocky Mountain. Research Station. Fort Collins, CO, USA.

Sæpórsdóttir, A. D. (2010). Planning nature tourism in Iceland based on tourist attitudes. Tourism Geographies, 12(1), 25-52. doi:10.1080/14616680903493639

Scholz, R. W., \& Tietjen, O. (2002). Embedded case study methods. Integrating quantitative and qualitative knowledge. Thousand Oaks: Sage.

SEPA - Swedish Environmental Protection Agency. (2002). Fulufjällets Nationalpark. skötselplan. SNV Rapport 5246. Stockholm: Naturvårdsverket.

SEPA - Swedish Environmental Protection Agency. (2009). Swedish nature conservation. 100 years. Bromma.

Steg, L., Berg v.d., A. E., \& de Groot, J. .l. M. (2012). Environmental psychology, an introduction. Chichester: Blackwell.

Stokols, D., \& Altman, I. (1987). Handbook of environmental psychology. New York, NY: Wiley.

Swarbrooke, J., \& Horner, S. (2007). Consumer behavior in tourism. Butterworth-Heinemann: Oxford.

Visit Sweden. (2015). Nature and outdoors. Retrieved October 10, 2014, from http://www. visitsweden.com/schweden/erleben/Natur-Outdoors/

Wall-Reinius, S., \& Fredman, P. (2007). Protected areas as attractions. Annals of Tourism Research, 34(4), 839-854. doi:10.1016/j.annals.2007.03.011

Wallsten, P. (2003). The "inside-out" process: A key approach for establishing Fulufjället National Park in Sweden. Journal of Mountain Research and Development, 23(2), 227-229.

Weaver, D. B. (2008). Ecotourism. Milton: Wiley. 